\title{
The Commercialising of British Men's Basketball: Psychological Contracts Between Coaches and Players in the Post-Bosman Game
}

\author{
Valerie Owen-Pugh
}

\begin{abstract}
This paper explores the psychological contracts of male players and coaches in British commercial basketball, and the ways in which these might be shaped by the constraining and enabling pressures of athletic talent migration. It draws on qualitative interview data to argue that commercialising changes in the game's recent history have led to the emergence of divergent forms of psychological contract between coaches and players. These have promoted the interests of the game's migrant Americans at the expense of its indigenous athletes. In particular, while the Americans reap the benefits of a high social reputation, material rewards and career development, many indigenous athletes working in the top-flight clubs struggle to gain remuneration and court-time and must fall back on their own resources to build self-confidence and self-respect. It is argued that this marginalising process was intensified following the Bosman ruling of 1995, which led to the exodus of many skilled indigenous players from the UK and prompted the commercial league to make more extensive use of Americans. Interpretation of the study's findings is informed by Elias' theory of established-outsider relations.
\end{abstract}

IN GAME SPORTS WITH AN INTERNATIONAL FOLLOWING, SUCH AS FOOTBALL, ICE HOCKEY and basketball, the commercialisation of sport is transforming the career opportunities open to talented athletes. Provided they have marketable skills and are able to follow a migrant lifestyle, they can aspire to high salaries, and the opportunity to hone their playing skills in the company of other elite performers (Olin 1984; Maguire 1988, 1992, 1999; Galily and Sheard 2002). Moreover, it is arguable that athletes are gradually gaining bargaining power at the expense of their clubs and national bodies (Stokvis 2000). Such a transfer of power has certainly been taking place in recent years within Europe, where, following the Bosman ruling of 1995, athletes with EU passports have benefited from the loosening of clubs' control over out-of-contract players, and from the relaxing of eligibility quotas restricting non-nationals' access to teams (Maguire 1999; Gardiner and Welch 2000; Parrish and McArdle 2004). However, the freedom of movement won by athletes such as Bosman has been at the expense of player development. Clubs able to hire talent on the open market are less likely to invest in youth training, while indigenous players find themselves having to compete against foreign workers for coveted places on elite home teams (Olin 1984; Maguire 1988, 1999; Gardiner and Welch 2000; Galily and Sheard 2002; Dabscheck 2004, 2006).

The social changes associated with sports migration are currently being debated within two distinct, but overlapping, academic traditions. Writers on sports regulation and public policy have deliberated over issues such as: the increasing internationalisation of national teams; sports organisations' entitlement to exemption from free-market legislation; and mechanisms for promoting the development of commercially marginalised clubs and athletes (Gardiner and Welch 2000; McCutcheon 2000; Parrish and McArdle 2004; Dabscheck 
2004, 2006). In contrast, sports sociologists have highlighted the national struggles associated with migrant flows, showing, for example, how such struggles find expression in the viewpoints and behaviour of supporters and athletes (Olin 1984; Maguire 1988, 1999; Galily and Sheard 2002; Falcous and Maguire 2005, 2006; Klein 2007). However, to date, few authors from either tradition have considered how these commercialising changes might impact on the relationships between athletes and coaches. One notable exception is the work of Stokvis (2000) who argues that free agency is leading to the individualising of athletes' subjectivities and consequently to increasingly impermanent and conflictive forms of coach-athlete alliance. Another is Galily and Sheard's (2002) study of the Americanising of Israeli basketball. Though primarily an account of the manoeuvring between Israeli governing bodies over foreign-player quotas, this study showed how commercialising processes were obliging coaches to apply different discipline codes to migrant and indigenous players. One coach is quoted as saying:

You cannot really treat all players alike on this kind of team.... It is not just that they are better players with different standards.... In a way they are not expendable, as most players are ... If a local player behaved inappropriately, I would have punished him without blinking. However, if an American player acted the same way I was in serious trouble. Even if I wanted to act according to my standards, I knew that the team was very much dependent on the player and therefore I had to think twice ... It is definitely not healthy for the team ... You can almost talk of two classes of players on your team, after all, they got paid much more than the local players. (Galily and Sheard 2002: 52)

In management terms, this coach appears to have been working to two divergent forms of 'psychological contract' (see Anderson and Schalk 1998; Maguire 2002) in which he applied different sets of professional standards both to his players and to himself, depending on their nationality and commercial value. The aim of this paper is to consider whether a similar dynamic might be present in other national contexts. This aim will be pursued by offering a case-study of British basketball which, like the Israeli game, is heavily Americanised. The paper will seek to make connections between sports policy and regulation, struggles over national identity, individuals' work interdependencies and human subjectivity. In so doing, it will offer an interdisciplinary analysis, drawing on the literatures of sports law, psychology and management as well as sociology.

The paper will commence by showing how recent commercialising changes, including the Bosman ruling, have worked within British basketball to shift the balance of power away from indigenous players and towards their American counterparts. It will then consider how such developments might best be theorised before turning to explore the ways in which this game's top-flight coaches and athletes understand their working relationship; at this point, reference will be made to qualitative interview data. Finally, the paper will seek to reconcile data with theory before final conclusions are drawn regarding indigenous player development in this sport.

\section{The commercialisation of British basketball}

Maguire (1988) describes the early commercialising stages of British basketball, showing how the owners of some top flight clubs in England's National Basketball League (NBL) built interest in the game by attracting North American players and coaches to the UK. In the process, these entrepreneurs transformed it from a white, amateur sport to one in which, in its uppermost men's division, the majority of players were black and $30 \%$ were waged Canadians or Americans (the term, 'American', will be used in this discussion to refer to both national groups). For these club owners, the introduction of skilled foreigners made good commercial sense. They did not have sufficient funding to attract elite European players ${ }^{1}$, and the pool of $\mathbf{2 0 0 0}$ or so skilled graduates produced each year by American colleges

\footnotetext{
${ }^{1}$ Information supplied by key informant with the BBL, via e-mail correspondence (3 June 2003 - 30 October
} 2007). 
allowed them to employ powerful players at a modest cost. Employing the Americans also offered them indirect marketing advantages: for example, there is a prevalent belief in the game that the American style of play is more entertaining than the European and so more attractive to paying spectators (Britball 2000). Despite the expansion of the game, however, the English amateur lobby remained concerned over the presence of so many Americans. Its concerns were not ill-founded. Maguire's statistics imply that, by 1987, up to three out of the five 'starter' players on top-flight teams were likely to have been migrants, while the indigenous players were largely confined to bench roles. The groups did not simply differ in their access to court-time: while the Americans were paid for their services, the indigenous Britons were amateurs. Maguire reports that disputes between the amateur and commercial lobbies over the presence of the migrants became increasingly acrimonious, and led eventually to the launch of a break-away commercial league, the British Basketball League $(\mathrm{BBL})$. The BBL has since co-existed with the NBL in an uneasy interdependency, located above, but detached from, its developmental structure.

Since the Bosman ruling, the game's amateur and commercial lobbies have once more found themselves in disagreement. In the light of this ruling, most EU national bodies, including the NBL, agreed to allow EU passport-holders unrestricted access to their teams while continuing to restrict the registration of other non-nationals to one or two per team. ${ }^{2}$ However, anticipating that their British starters would immediately take advantage of the ruling to look for better-paid work in European clubs, the BBL took a non-conformist line. Confident that its decision was unlikely to be challenged in court by EU players seeking access to its teams $\mathrm{s}^{3}$, it adjusted its league regulations to permit teams to register up to five non-national players whilst also reserving five places for players with British passports. The 'brawn drain' anticipated by the BBL did indeed come about; post-Bosman there have been at least 35 British players playing in European leagues every season, an average loss of two to three per BBL team. ${ }^{4}$ However by 2002, BBL teams were registering an average of 4.91 non-nationals in their five starter roles. ${ }^{5}$ Allowing for the presence of dual nationals and a very small number of indigenous elite performers who preferred to work in the UK, this effectively left only their bench roles still open to British players. The BBL teams had effectively become divided into North American 'haves' and British 'have-nots': salaries, court-time, career choices and free agency belonged almost unequivocally to the migrant group. Unsurprisingly, this decision was subject to considerable criticism by the amateur lobby, and by many spectators who wanted to see more British players on court (Taylor 1999, 2002; Britball 2000). Recently, the BBL has modified its position, reducing the number of permitted non-nationals to four in 2004 and three in 2006. However, in 2006, it also abandoned its commitment to reserve places for British players, finally allowing EU passport-holders unrestricted access to its teams.

It should not be assumed that the British bench players are without talent or ambition. Given the paucity of 'grass roots' development opportunities in the UK, indigenous players often only recognise their potential when it is too late to capitalise on it, for example, by negotiating scholarships to American colleges, a typical development path for indigenous youth players (Maguire, 1992, 1999). Furthermore, they are as likely as their American teammates to subscribe to the conventional sporting values of hard work, achievement and refusal to settle for 'second best' (Adler and Adler 1998; Jones et al. 2005; Seippel 2006). However, if they want to develop their skills, these players face an uphill struggle; in the BBL, they will encounter the most challenging match opportunities in the UK but will probably be offered little court-time by their coaches; if they move to an NBL team, they will gain courttime but lose access to the best competition. The option of moving to a paid job in mainland Europe remains outside their grasp unless they can show hard evidence of their competitive skill (e.g. match statistics and video-footage) to commercial agents. Regardless of their

\footnotetext{
${ }^{2}$ Information supplied by key informant with the NBL, via telephone interview (September 2007).

${ }^{3}$ See n. 1

${ }^{4}$ ibid.

${ }^{5}$ ibid.
} 
potential, therefore, these players can find themselves unable to progress beyond team roles that offer little monetary return or development.

It is arguable that these players' situation is a form of exploitation, comparable to the physical damage that athletes can do to themselves when their love of sport and desire to succeed leads them to develop an obsession with weight or body shape (Jones et al. 2005), to use performance-enhancing drugs (Waddington and Murphy 1992; Morgan 2006), or to play through injury (Roderick et al. 2000; Roderick 2006; Murphy and Waddington 2007). Writers such as Wilson (1992: 75) would take a Marxist line, stressing that in sport, as in other work contexts, 'the division of labour alienates men from one another and from themselves'. This radical viewpoint obliges us to question the extent to which the 'traditional' sporting values of hard work, loyalty and athletic excellence serve hegemonic interests (Murphy and Waddington 2007). However, while Marxist theory throws much-needed light on the political functions of sport, and the plight of marginalised sports workers, it can be argued that it under-represents the complexity of sports development processes. For example, in reducing subjective experiences of sport to 'alienation', a Marxist interpretation takes no account of the positive experiences it engenders in those who play and watch it (Sabo et al. 2005; Seippel 2006). Furthermore, even the negative experiences engendered by commercialised sport, such as the cultural dislocation encountered by migrant athletes (Maguire 1992), can often be difficult to interpret from a commodification perspective. Arguably, also, Marxist theory offers us insufficient purchase on the ways in which sports development can come to be associated with struggles over gender, racial and (as in the present case) national identities (Maguire 1988, 1992). Moreover, the conventional Marxist formula, contrasting human wages with surplus value, is turned on its head in commercial sport, where some labourers can come to wield considerable economic power while (as in British basketball) the clubs that employ them may struggle to break even (Olin 1984; Maguire 1988, 1992, 1999; Stokvis 2000).

An alternative solution is offered by Elias' figurational theory (Elias 1978, 2000), which allows us to view the commercialisation of sport as one among a number of commingling global processes, including processes of pacification, democratisation, individuation and privatisation (Maguire 1988, 1999; Waddington and Murphy 1992; Dunning 1993). It visualises these processes as the 'interweaving of countless individual interests and intentions' (Elias 2000: 312), an interweaving that, though it has no agency of its own, can come to constrain human opportunities and choices and, because of the complexity of the power relations involved, will have unintended and potentially unforeseeable consequences. A key advantage of Eliasian theory is that it can be applied across all levels of social analysis. For example, sports sociologists offer examples of its use at global, national, local and even inter-personal levels (Dunning 1993; Maguire 1998, 1999; Galily and Sheard 2002; Falcous and Maguire 2006; Stokvis 2000). It is also possible to make connections across these levels of analysis, including (if we take the present study as an example) looking at the interrelationship between national struggles and individuals' work relations.

Elias' concept of the 'figuration' (the relational networks of obligation that bind individuals together) helps us to conceptualise the professional choices faced by coaches and athletes. For example, both parties can be understood as individuals working for career development within a complex network of enabling and constraining influences, ranging from international legal frameworks and governing body regulations to the social obligations owed to families, teams, clubs, sponsors and media groups. Arguably, coaches face additional constraints created by their professional position, in that they must also reconcile conflictive obligations to their athletes on the one hand and their clubs on the other (Roderick et al. 2000; Stokvis 2000; Kelly and Waddington 2006). In Americanised basketball, coaches must also find strategies for managing the power differences between migrant and indigenous players. As we have seen, Galily and Sheard's coach thought twice before offending a migrant player. Figurational theory would predict a similar outcome in the British game. Given the relatively low wages on offer in the UK, migrant players are unlikely to sign 
contracts for more than one, or at the most, two seasons ${ }^{6}$; indeed it is not uncommon for them to leave teams mid-season if they believe that they can obtain better pay and conditions elsewhere (a similar situation exists in British ice-hockey, another marginalised and Americanised sport - see Maguire 1999). Unlike some other game sport contexts (Walton 2001; Kelly and Waddington 2006) star players can therefore find it relatively easy to leave their clubs if they are unhappy. If we also take into account the commercial coach's heightened vulnerability to dismissal (Walton 2001, Murphy and Waddington 2007), it is arguable that the parties' opportunities to constrain each other's behaviour are relatively balanced or, in the case of a team's 'star' player, might favour the player rather than the coach. Coaches might therefore be inclined, as Galily and Sheard note, to adopt a light touch when dealing with their Americans. In contrast, coaches want support players to play hard during training and be effective substitutes during matches. Here, the power balance between coach and players will undoubtedly favour the coach since, during matches (as opposed to training), he may make little use of their services. While bench players could improve their power significantly if they were able to develop their skills, it would not be in a coach's interests to allow this to happen (after all, the best bench players can also be hard to replace). In dealing with indigenous players, therefore, coaches might be likely to assert their personal authority and possibly even restrict their players' development. It might be said that, in dealing with their migrant players, coaches would need to prioritise support over control while, in dealing with their indigenous players, they would be obliged to prioritise control over support.

Also relevant to the present study is Elias' 'established-outsiders' (E-O) theory. Although he did not formally develop this theory until late in his career (Elias and Scotson 1994) much of his writing is taken up with historical analyses of established and outsider groups, showing how their manoeuvring for power opportunities could be realised as disputes over the ownership of social values and practices; for example, his writing offers many examples of groups seeking to set themselves apart from others by espousing 'correct standards' of behaviour (Elias 2000). A key criterion for the presence of E-O relations is the existence both of interdependency and a significant power difference between two social groups. Both of these conditions certainly apply to British basketball: while the starters and bench players are interdependent, the Americans have a significant advantage over the Britons in terms of their skill, social reputation, and the social alliances they are able to form with coaches, club owners and sponsors. In the presence of such conditions, Elias would argue that the weaker group (the 'outsiders' - here the indigenous players) will identify with the values and practices espoused by the more powerful group (the 'established' - here the migrants) while the latter will work to defend their interests from unwanted incursions by the former. While it may appear a misnomer to classify the migrant Americans as an 'established' group, Elias' distinction between 'established' and 'outsiders' is not based on historical claims to territory. Rather, it is simply a question of which group has the greater access to power opportunities. Indeed, it is possible for E-O relations to be reversed at different levels of analysis. For example, Falcous and Maguire (2006) offer an analysis of the discursive processes used by America's National Basketball Association (NBA) to promote American basketball in the British media; in their study, the NBA becomes an 'outsider' group working for acceptance by the British sports 'establishment'. E-O theory helps us to understand the ways in which established groups might appropriate community dialogue processes to reinforce their hold on power. For example, Elias and Scotson (1994) refer to the strategic use of 'praise' and 'blame' gossip to reinforce cohesion among the ranks of the established while keeping outsiders at a distance. This theory also offers us insight into the subjective plight of the outsiders. For example, it can be argued that, in aspiring to the social values promoted by the established group, outsiders must also aspire to its rejection of themselves (Elias and Scotson 1994).

We must now consider how Elias' theory might help us interpret the psychological contract. In the mainstream management literature, this contract is conventionally understood as the unspoken expectations of obligation and benefit held by employees and employers (Herriott

\footnotetext{
${ }^{6}$ ibid.
} 
et al. 1997; Anderson and Schalk 1998). Since it addresses the employee-employer interdependency, it is, in a sense, already construed in an Eliasian manner. However, it is often interpreted in the literature simply in terms of dyadic exchange. Elias' figurational theory, on the other hand, not only allows us, but requires us, to locate the interdependency of individuals within their wider social context, that is, to consider the enabling and constraining pressures impacting on their relationship.

Models of the psychological contract acknowledge the salience of many different forms of work obligation, ranging from job commitment and career development, to hours worked and salary payable, and loyalty and respect (Maguire 2002). For present purposes, these wide-ranging obligations can be thought of as falling within 'educational', 'managerial' and 'emotional' domains. In sport, the educational domain of the contract can be interpreted as obligations to instruct and learn. Coaches have social obligations to instruct athletes in the technical aspects of their sport, build their fitness and motivation, and enter them in graded competition. In return, athletes have obligations to conform to the vision of their coaches, submit to his/her training regimes, adopt a competitive attitude and work co-operatively with team-mates (Adler and Adler 1998; Potrac et al. 2002; Poczwardowski et al. 2002; Jones et al. 2003; Jowett 2003). The managerial domain is analogous to the commercial deals struck between athletes and sports clubs, in which athletes commit to high performance while coaches adopt managerial responsibility for ensuring the payment of wages and other benefits, and also the presence of safe and satisfactory working conditions (Walton 2001; Kelly and Waddington 2006). The emotional domain includes such things as mutual demonstrations of loyalty, respect and trust, and readiness to agree over values, practices and goals (Adler and Adler 1998; Poczwardowski et al. 2002; Jowett 2003; Potrac et al. 2002; Jones et al. 2003). This model of the contract will now be used, in conjunction with Elias' theoretical ideas, to explore coach-player relations in British basketball.

\section{A case study of coach-player relations}

The research described here was a retrospective case study (Flick 2007: 45) in which players and coaches working in the upper echelons of British basketball were asked to explore their professional interdependency and its influence on their career development. It conforms to a 'post-positivist' or 'naturalistic' paradigm in which realities are assumed to be multiple, constructed and holistic, and time-, context- and value-bound (Lincoln and Guba 1985: 37). The study adopted a 'tight' research design in the sense that procedures for selecting participants were prestructured, and questions asked were chosen with reference to theory (Flick 2007). A 'snowballing' approach was used to maximise the diversity of perspective among participants, a procedure that Guba and Lincoln (1989) refer to as 'maximum variation sampling'. In this procedure, participants were asked to suggest the names of individuals who differed from them in terms of predetermined characteristics, including nationality, race, experience of the game, and current team role. This procedure generated a matrix of potential participants. In drawing up the final pool of participants, care was taken to ensure that these social markers were equally represented. While this sampling procedure does not ensure a representative sample of opinion, it can be the only way of accessing professional sports workers, who are notoriously reluctant to agree to be interviewed by 'outsiders' (Roderick 2006).

Face-to-face semi-structured interviews were carried out between 2004 and 2006 with ten male players and seven male coaches in the BBL and in NBL Division 1. At the time of the study, 12 participants (including five coaches) were working, or had recently worked, for a BBL club while six (including two coaches) had worked, or had recently worked, within NBL Division 1. The decision to include some NBL personnel was taken in order to maximise diversity of opinion but, as it turned out, it also offered the only means of talking to indigenous players who were also regular starters for their teams. Most participants (including those in NBL Division 1) had previous experience of working in other top-flight British clubs. Of the seven coaches interviewed, two were American, and five were British. Out of 10 players interviewed, three were work-permitted Americans, all of them regular 
starters for their teams, one was an American with acquired British nationality, and six were indigenous British players varying in their access to starter roles (two were regular starters, two were occasional starters and two were regular bench players).

The interview questions explored participants' understandings of: their work obligations; others' work contributions; the ways in which coaches and players might enable or constrain one another's careers; the strategies used by bench players to gain court-time; the relations between migrant and indigenous, and black and white, players; coaches' and players' obligations to commercial stakeholders; and the ways in which third-party loyalties, including loyalties to sponsors and national and ethnic groups, could impact on the coachplayer relationship. Participants were asked to draw on their lifetime's experience of the British game, rather than make close reference to current working relationships.

Analysis of the data was guided by categories generated in advance with reference to theory, previous research and an initial reading of the transcripts; these were modified as analysis proceeded and new themes were identified. This was therefore an example of 'conceptdriven', rather than 'data-driven' coding (Gibbs 2007). For the purposes of the present discussion, the data was analysed with reference to two overarching questions:

i. what is the psychological contract between players and coaches at the professional end of British basketball?

ii. how does the contract reflect the polarised power relations between American and British players?

\section{Findings}

The psychological contract

The data was initially analysed to clarify participants' understandings of the contract's three domains. Its key findings will now be summarised.

\section{The educational domain}

All participants acknowledged the educational domain of the contract, agreeing over such things as the need for hard work, a commitment to achieve, and a willingness to be honest and constructive when offering feedback. It was widely agreed that coaches should be sensitive to, and build on, players' individual strengths, and that players should be prepared to defer to their coach's vision, systems and style of play. However, all participants understood that the BBL's priorities were commercial rather than developmental. As one BBL bench player put it:

I'm managed. I wouldn't say I'm coached. ... Professional basketball in this country is man management. It's recruiting in the summer and then it's keeping them all facing the same way. It's not coaching. ... Basically you bring them in, they use you, you use them and then they move on. ... I'm not taught how to screen any more or how to curl, how to dribble the ball. Whatever stage I'm at, if I want to get better I need to go off and do that myself.

Even so, many of the younger players, in both the leagues studied, acknowledged an unmet need for further skills development.

\section{The managerial domain}

The rewards that participants were looking for could not be reduced simply to wages and conditions. All professed their love of the game and several (most notably but not only the 
Americans) expressed themselves lucky to be able to 'live the dream'. However, many participants, both American and British, also referred to the need for a 'work ethic' and the need to maintain 'professional standards'. Some stressed the value of a commercial game for player development, arguing that it would raise performance standards in the long run. Many considered that commercialisation was equalising opportunities for white and black players. These participants explained that, in the past, coaches had been inclined to place black players in roles requiring 'athleticism' and white players in roles requiring 'intelligence', but that the pressure to win was increasingly obliging them to see players, not as black or white, but as individuals.

However, it was clear that commercial priorities could also come between players and coaches. Money and payments in kind were a source of frustration for those who felt they were denied them or were not receiving what they were worth. As a consequence, coaches often became caught up in resolving disputes between players and management over unmet expectations. It was widely acknowledged that players could often feel constrained to play through injury, and that coaches could often feel constrained to allow it. Participants also referred to ways in which a club's star players could trade on alliances with club directors and sponsors. In such cases, coaches' careers could be on the line, as in the following account:

I remember a situation with a player who I've worked with ... and he's a difficult player but a very, very effective player. ... He had a row with a coach ... and pinned him against the wall by his throat. [The coach] went to the club management because he wanted him sacking and the management refused to sack him and so the coach left. Management wouldn't support the coach because he was an outstanding player. They wouldn't do it, but you know I think that was the management's loss. (British coach, BBL)

\section{The emotional domain}

There was universal agreement that the foundation of a strong coach-athlete partnership lay in mutual respect, trust, loyalty and honesty. Participants of all backgrounds acknowledged the value of having a coach who was prepared to push players hard, provided that this was done in ways that were constructive and not humiliating. There were many references to coaches acting as 'mentors' and 'father figures', but participants also acknowledged that insensitive coaches could destroy players' confidence. It was understood that both coaches and players could commit abuses of trust. For example, there were references by players to coaches who failed to keep their promises, and by coaches to players who had not lived up to their curricula vitae (CVs). Participants recognised that both parties could abuse their power in subversive ways that were difficult to confront, such as coaches forcing players to do unnecessary additional training or players deliberately missing shots in matches.

Participants also referred to emotional problems associated with their work, such as the 'burn-out' associated with migrant lifestyles, and the need for players and coaches to 'stay confident'.

For many, the ultimate solution to all of these problems was to remain vigilant and be selfsufficient. It was noticeable that, in contrast to the younger British players, who were inclined to apologise for acting in their own interest, the North Americans all appeared to be comfortable with and often proud of their self-reliance. The following comment was typical:

This is my 14 th year of playing ... and I like to think of myself as a very self-motivated person. There are some players that need coaches to push them all the way to do everything. There are some players that are just self-motivating. ... I think it's important for a coach to push them but I think for a player or an athlete really - well at the end of the day it's up to that athlete, that player to push themselves. The coach is there to encourage and help. (Veteran American player, BBL) 


\section{Summary}

This analysis revealed widespread agreement over the terms of the contract. Even so, its inherent complexity appeared to make it impossible for the parties to meet all of their obligations to one another all of the time. The risk of contract violation appeared to increase when coaches and athletes were obliged to take account of their formal commitments to club owners and sponsors.

\section{The national divide}

For the purposes of this discussion, transcripts were explored for themes relevant to: the relative professional standing of North American and British players, including the ways this appeared to have been influenced by the Bosman ruling and its aftermath; relations between either national group and their coaches, including the strategies open to British bench players to gain court-time; and participants' career development strategies.

\section{The professional standing of British and American players}

The majority of British participants, both coaches and players, aspired to American values and greatly admired the skills of the migrant players. There were many references to 'American pedigrees' and the quality players produced by America's National Collegiate Athletic Association (NCAA). They also talked about the valuable role the Americans played as ambassadors for the game, and referred approvingly to the technical advice the migrants often gave to British players - and indeed to some coaches. There was little acknowledgement that the Americans' skills might be exaggerated. However, one young bench player was willing to talk, though only 'off the record' about what he described as a 'conspiracy': he felt that his British coach was so American in his speech, mannerisms and sympathies that he had effectively 'gone over to the other side'. For their part, the Americans were aware and clearly proud of the fact that they were highly regarded.

Few participants referred to the strengths of British players beyond acknowledging that the best British players could do better for themselves in Europe. However, one American coach acknowledged the power of the few British starters still working in the BBL, referring to them as a potential focus for team resistance: 'someone who's been around and who's the local guy can be very powerful influence - he can take on coaches and undermine them!'.

Some older British participants expressed anger at the way in which the BBL had responded to the Bosman ruling. Both players and coaches talked of the damage done to indigenous player development. One British player graphically described how the changed regulations affected his confidence and career prospects:

When I first started playing at 16 for the senior team, at that point only two Americans were allowed on your team. ... I didn't play loads for the senior team because I was just a little kid but I still got to play, as far as I was concerned, enough for me. I was happy with what I was getting. When I moved to [name of club] I was still happy with what I was getting and then something changed. The Bosman ruling came in which dictated that you could have five and in some cases six, maybe seven [Americans], depending on work permits or if your mum or your dad was born in England, all of that kind of stuff. And then it changed, my court time was just gone! And if you're not playing regularly on your domestic team, how do you expect to do well on a national level? It's not going to happen. So, in terms of your career progression, then it's greatly reduced because you're not getting competitive experience week in, week out. You're not getting game fitness, you've only got practice fitness. And once you're not playing regularly your confidence starts to ... you know, if your coach doesn't put you on, eventually you're going to be "am I that bad?" you know, forget how much I was revered or looked up to as one of the top 
three players in the country for my age group, all of a sudden you're not playing at all - "well I must be really not that good any more".

\section{Player-coach relations}

All the British players interviewed considered that British and American players were treated differently by their clubs. For example:

Some English players feel very resentful of Americans.... They feel they are at least the same ability level, however the Americans still get paid more, they play more, they get treated with more respect. ... If part of the deal on your contract is to get a house and a car, the Americans will get a nicer house and a nicer car and the British players will get something else. If part of your contract is to do ten hours a week coaching, the Americans may get paid slightly more an hour than the English player. And obviously, that's going to spill over into the team dynamics in the changing room. When you're training, there will be resentment there. (British player, NBL)

British players also referred to being treated with disrespect by their coaches. These were the views of two BBL bench players.

You don't have a real team chemistry because a lot of the time it's the Americans and the English guys and a lot of coaches will talk about the English guys in a basically derogatory way ... any time they mention the English players it's not in a good way, it's like "Oh he's an English guy", basically assuming he can't play. It's a slight at English players.

Sometimes I've been on teams where the coach will talk to the American players totally different to the way he talks to an English player. ... He'll ask an American player to do something and he'll tell an English player to do something.... There's a total change in his respect ... as though you're not really as important. And you feel it as well, a lot of times you feel like you're just making up numbers, you're just there to practice and it doesn't matter really what you do in practice you're not going to play [in competition]. It takes a lot of character to stay, stick with it.

These players were adamant that British and American coaches could be equally discriminatory. For their part, none of the coaches interviewed appeared to be aware that they might be conveying differential levels of respect to their British and American players. Given that they were a self-selected group (having agreed to participate in a study on coachplayer relations) it is quite likely that they tried to treat all their players as fairly and honestly as they could. A coach that one of these players appeared to be referring to had been asked to participate in the study, but had refused.

\section{Accessing court-time}

Participants disagreed over whether or not it was possible for bench players in BBL clubs to gain the court-time they needed for development. Some considered that they could if they give their coaches a reason to play them. These participants considered that it was down to hard work, doing extra training and making the best possible use of any court-time they were given, for example, by being very vocal and playing strong defence. This was the view of a British coach:

If the players are good enough they can play. If they get to a standard where they are so good that they're too good for the BBL they go into Europe and they earn a lot of money. ... I always say to English players who've got that "well it's all Americans", I say "hey, you get yourself to a standard where you can compete with them and you'll be on the floor". 
However, others felt that this was unlikely, for a variety of reasons. Some participants considered that coaches had little room for manoeuvre, given the commercial value attached to winning matches. This was an American coach's view:

Well, you have to win, so you might have to play guys that you hate. ... Everything that they stand for you can't stomach, but if you don't play them you're probably not going to win. If you don't win you don't have a job. ... That's the dilemma. And guys that work hard and you want to play maybe just aren't going to cut it. They aren't good enough. So that's a dilemma for a coach.

Some participants pointed out that clubs also needed to justify their Americans' workpermits. For example:

If you're bringing five Americans over to this country to play on your team, Americans are supposedly better than English players. So in order to justify bringing Americans over here, they've got to show that there's no-one in the British workforce that can do this job as good as this American guy. Traditionally Americans get paid more money than English players and no-one in the BBL is going to pay an American more money than an English player and allow the coaches to put the English players on longer than the Americans. It's as simple as that. Regardless of ability, that's what it boils down to. (Veteran British player, NBL)

Other participants acknowledged that keeping star players on court also kept sponsors happy. Some argued that the only realistic opportunity for bench players to gain significant court-time lay in the 'lucky' chance that the starter players they were covering succumbed to injury.

The importance of the bench players' support role was widely acknowledged. Many participants, both coaches and players, British and American, stressed that it was important for them to put everything they could into developing that role, of 'being the best bench players they can be'. However, at times this view appeared to be offered with a degree of defensiveness. For example, one American BBL player was very forthright:

I have no control over [allocation of court-time] you know, that's the coach's job. ... But you've got to ... know your role on the team. ... For the team to be successful you have to know your role, even if you're on the bench or you're playing. ... When you start to complain about playing time, your problems start, unnecessary problems.

\section{Career development strategies}

Many participants acknowledged that, in sport, career success was often a matter of chance, such as 'being in the right place at the right time', 'knowing the right people' and 'who you are seen by and who that person might know'. They also talked about the ways in which their personal career strategies could be influenced, for better or worse, by the interventions of families, coaches and sponsors. All the American players were confident of being able to further their careers in the game. The younger ones generally talked about selling their services to the highest European bidder, the older ones to moving into developmental careers associated with basketball, such as coaching and teaching. The British players had similar ambitions. While a number of the British veterans were already becoming very actively involved in teaching and coaching, the young players wanted to move to Europe. This was a typical comment:

My aims are to try and get out to Europe and try and play professionally out in Europe, because playing here in [name of club] was a stepping stone on my way there, to try and develop me as a player to get out there. I've just got to get my name out there, get video tapes from games and stuff and get it out there. And in terms of development as a player, that's something I've just got to work at every day, put the 
hours in the gym, put the hours in over the summer when everyone else is resting and going on holidays and that, just putting the work in to try and get better.

However, while the move into Europe was clearly a realistic ambition for the Americans, who already had commercial agents and strong match CVs, it presented a significant challenge to the indigenous players who lacked both. One BBL bench player described how difficult it could be to access taped performance highlights. Referring to a British coach (also not among those interviewed), he said:

We played [name of club] ... and one of our [American] players asked for a game tape. I heard the coach say "yeah, that's cool". I had a good game that game as well so I've gone up to him and asked him if I can get hold of a game tape and it's "no we haven't got it", straight after I heard him. ... I was standing behind a pillar and I've walked around and asked him and it's ... "no, no, nobody's recording the game today".... Now why would [he] say that?

It was suggested earlier that differential power relations might oblige coaches to support their migrants but work to control their indigenous players. This story appears to support that contention. It will be revisited later in this discussion.

\section{Summary}

At the time of this study, the BBL had just begun to reduce its foreign-player quota. However, it was evident that, for the indigenous players interviewed, this regulation change made little or no difference to their situation. As far as they were concerned, the 'returns' offered by the top flight clubs to their athletes still discriminated between players on national grounds. It was not simply a question of the national groups being offered different rates of pay, although differential payment was certainly a contentious issue. Rather, many felt that their personal contribution to the game, and their nationality, were both significantly undervalued. As we have seen, these perceptions of being 'second-class' were voiced by indigenous players both in the BBL and (perhaps more surprisingly) the developmental NBL. For their part, the coaches interviewed were generally prepared to acknowledge (like the coach quoted by Galily and Sheard) that differential treatment did take place but, for a variety of reasons, they felt that their hands were tied.

\section{Discussion}

This study appears to confirm the presence of contrasting coach-player contracts in Britain's top flight basketball clubs. The American players shoulder primary responsibility for winning matches and, in return, are offered good money, guaranteed court time, career development and respect. The indigenous players perform essential support functions but receive little or no money, court time or career development. Sometimes, respect is also hard to come by. It must be stressed that these observations are generalisations. For individual players and individual coaches, the reality is undoubtedly very different. Indeed, key features of the contract, including the differential rates of pay, may be beyond some coaches' power to control. Furthermore, it must be acknowledged that coaches would need to apply differential contracts to starters and bench players even in the absence of a migrant workforce. However, the differential contracts identified here were also identified in the NBL's Division 1, where work-permitted foreigners are currently limited to two per team. Consequently, they could not be explained simply in terms of differing team roles. Indeed, Maguire's (1988) study, which first recorded the divergent reputations and wages of the two national groups, was carried out at a time when just under half of all starter positions were likely to have been filled by British players.

However, this national struggle cannot be understood simply in terms of differential contracts. It must be recalled that some coaches also discriminated between players on racial 
grounds but, nevertheless, there appears to be a fair amount of racial harmony within the British clubs. To understand what is going on here, we need to revisit Elias' E-O theory. It will be recalled that, for $\mathrm{E}-\mathrm{O}$ relations to be present, there needs to be a significant difference in the power opportunities possessed by two interdependent groups. In the case of the two racial groups, it is arguable that there could be little overall power difference between them, and therefore no significant E-O relations, at club level: while club owners and directors are predominantly white, black players outnumber white players overall and dominate the starter positions; starter and bench roles are taken by both racial groups. It must be stressed that this conclusion could only apply at club level, where the black players' athletic skills and their commercial value to their clubs may offer them some respite from their wider social marginalisation (Lawrence 2005; Andersson 2007). It would not apply beyond the confines of club life. Indeed, the group analyst, Farhad Dalal (1998) offers a discussion of global racialisation processes that draws heavily on $\mathrm{E}-\mathrm{O}$ theory.

In contrast, given their differential access to power opportunities, the contrasting contracts offered to American and British players must be understood as part of a wider national struggle. It will be recalled that, from the perspective of E-O theory, an established group can be expected to force its superior access to power opportunities through politicised forms of dialogue. The interviews carried out here did indeed offer evidence of such dialogue. Eliasian theory refers specifically to established 'charisma' and outsiders' 'disgrace'. In this study, participants made many references to the 'gold-standard' CVs of American players. In contrast, British players not only expressed general frustration at their second-class status but variously testified: to overhearing derogatory comments from coaches and Americans about the skills of British players; to subtle differences in the modes of address used by coaches; and even to a coach's readiness to lie to a British player while being honest with an American. Given that these discursive strategies might be serving a policing function, it is relevant to note that almost all participants made reference in some way to the athletic principle of 'playing to your team role'. In the presence of E-O relations, this could be interpreted as an injunction to 'know your place'. This brings us to the British coach, and the role he may be playing in upholding the interests of the migrant players. From a figurational perspective, it would be argued that British coaches (and many British players too) might see power opportunities in allying themselves with the migrant players. Unlike the indigenous players, however, who have little to offer the Americans in return for their 'protection', indigenous coaches (and the few elite British players in the game) might be accepted as honorary Americans provided they kept the Britons at a distance.

From a non-Eliasian perspective, the idea of coaches 'policing' the interests of a dominant player group may appear unlikely. However, many academic studies have acknowledged the sports coach's role in transmitting community cultures and enforcing athletes' compliance with community norms, including norms of club loyalty, obedience to authority, and maintaining a good professional 'attitude' (Adler and Adler 1998; Jones et al. 2005; Kelly and Waddington 2006). Studies indicate, also, that the gate-keeping roles played by coaches accord them considerable power, particularly with regard to athletes in need of development (Jowett 2003; Kelly and Waddington 2006). Writers note that athletes will be inclined to accept their coaches' evaluations without question, and that apparent rejection by a coach can destroy their self-confidence and impair their performance (Walton 2001; Jowett 2003; Jones et al. 2005). Indeed, the polarised power relations between coaches and athletes are often implicated in studies of athlete exploitation (Jones et al. 2005; Murphy and Waddington 2007). Even so, coaches may not be fully aware of the power they wield. As we have seen, when they feel vulnerable to dismissal, they will feel constrained to act in the interests of their employers, even when this brings them into conflict with their own professional values. Indeed, it may not be necessary for coaches consciously to assert their power over athletes. Since they are taught the importance of maintaining a 'good attitude', athletes will often constrain themselves to remain in destructive relationships through a sense of personal obligation (Walton 2001; Jowett 2003; Murphy and Waddington 2007). This is not invariably the case of course; when an athlete is confident of alternative options, he or she may well walk away from such situations (Viner 2003). 
But are the relations between the American and British players likely to change? One means of answering this question is to think of the American dominance of British basketball as a form of cultural colonisation, and to assess the presence or likelihood of cultural resistance. For example, Klein (2007) takes this approach in his analysis of Dominican baseball. Elias (2000: 430) refers to two phases of colonisation, an early phase of 'assimilation' in which, 'the lower and larger outsider stratum is ... clearly inferior and governed by the example of the established upper group which, intentionally or unintentionally, permeates it with its own pattern of conduct' and a later phase of 'repulsion' or 'emancipation' in which the outsider group 'gains perceptibly in social power and confidence'. Arguably, at the present time, the Americans' colonisation of the British game is still in the assimilation phase. But is it possible that the indigenous players might find ways of building power? Studies of psychological contract violation show that, when they feel that their employers are failing to meet their obligations, employees will not only under-perform but engage in acts of resistance such as sabotage, theft and even violence (Pate et al. 2003). Maguire (1999) makes reference to indigenous player resistance in British ice-hockey taking the form of physical violence during matches. The present study offers no evidence of violent resistance but, even so, it was clear that the British players did not passively accept their second-class status. For example, they expressed their resentment to coaches and fellow-players, and they expressed determination to do the best they could for themselves in the face of difficult circumstances. There are signs of resistance, too, among many British supporters. For example, Maguire (1988) records the mixed reception accorded to the American players by the amateur lobby in the early days of the commercial game. These views continue to be expressed (see Taylor 1999, 2002; Britball 2000). It is possible to assess cultural resistance as the readiness of supporters to buy local rather than American club merchandise (Klein 2007). When such a test was carried out among BBL supporters by Falcous and Maguire (2005), 67\% expressed a preference for British merchandise.

Even so, it is difficult to see how the dominance of the Americans can be overcome unless the UK can produce many more players of international status. Even then, unless more British players can be persuaded to play in their home country's game, such a development would simply release more indigenous players into the global labour market. Of course, this does not prevent them from building a national reputation and even competing with the Americans in their home game; for example, such a reversal of fortune has been achieved by Dominican baseball players (Maguire 1999; Klein 2007). However, to bring the best British players into the home game would require significant commercial development. At the present time, the BBL may be seeking to promote such development by forging closer links with the NBA; for example, in 2005, they became contractually connected with its marketing arm, Synergie International (BBL 2005). Such a move would, of course, work to reinforce the dominance of the American players rather than reduce it. Even so, as Maguire (1999) emphasises, cultural colonisation does not simply lead to the dissemination of 'established' values and practices among the colonised; rather, as relations between the upper and lower strata develop, the practices and values of outsider groups can be taken up and popularised among the established; sport offers many examples of such contrary cultural flows. Consequently, though British basketball may well continue to be shaped by American interests for the foreseeable future, the game that evolves could become a blend of European as well as American practices.

Finally, figurational theory reminds us that, however powerful, individuals are almost always subject to some degree of constraint. Despite their power, the American players must find ways of handling the cultural disruption associated with a migrant lifestyle. Moreover, there are indications that they may find it increasingly difficult to sustain unchallenged reputations as 'gold-standard' players: as the ex-Yugoslavian states gain entry to the EU, its basketball labour market will become flooded with large numbers of highly skilled players who will have open access to employment in British clubs for the first time, and can reasonably be expected to find UK wages acceptable. Consequently, it appears inevitable that the Americans will lose much of their present dominance in the game. Two outcomes seem likely. Firstly, the bipartite struggle between American and British players will shortly become tripartite. Analogous to player relations in British ice-hockey (Maguire 1999), this struggle will 
predominantly be fought between the two elite groups of migrants, converging on the UK from West and East, while British players remain a comparatively marginalised group. Secondly, for the time being at least, elite performance in British basketball will continue to be associated in the national consciousness with foreign role models.

\section{Concluding comments}

It can be argued that the commercial history of British basketball is marked by two phases of migration. The first, described by Maguire (1988), commenced in the mid-1970's when its club owners first made use of American players (this transatlantic flow was not entirely oneway since small numbers of talented British youth players moved in the reverse direction, through winning sports scholarships to North American colleges). The second phase might be said to date from the Bosman ruling of 1995, which precipitated an outflow of skilled British players into Europe and (following the BBL's defensive reaction to the ruling) a heightened inflow of Americans. Since the ruling, migratory movement has been more complex, with many British 'rookies' moving directly from North American colleges to EU clubs, bypassing the British game altogether. At the same time, more American players are able to become naturalised British citizens; many of these dual-nationals will look for work in mainland Europe. In either case, the UK now qualifies as a 'donor' state since its investment in player development arguably works to the benefit of other EU countries (cf Maguire, 1992, 1999; Gardiner and Welch, 2000; Parrish and McArdle, 2004). We can speculate that, even in the first phase of migration, coaches will have offered differential contracts to British and American players, reflecting the Americans' higher levels of skill and commercial value. Such a conclusion would certainly be consistent with Maguire's (1988) study and with the findings of other writers who have documented the struggles associated with the Americanisation of amateur sport; Olin's (1984) study of Finnish basketball and Galily and Sheard's (2002) study of the Israeli game are both relevant here. However, following the Bosman ruling, this marginalising process intensified, with the balance of power shifting significantly in favour of the American migrants at the expense of the game's remaining indigenous players. However, the loss of power has not been confined to the game's indigenous players; British clubs and governing bodies have also lost much of their control over player movement.

The Bosman ruling may also have contributed to the eroding of British players' national identities. Theorists working in academic disciplines such as figurational sociology, social psychology, and psychotherapy suggest that human beings work to develop positive, group-referenced identities. Dalal (1998) draws on all of these perspectives in arguing that individuals gain emotional strength, and enhance their health and well-being, when they create positive mental images of (or 'idealise') the groups they belong to. This would suggest that, in the absence of skilled indigenous role models, British basketball players are left with a difficult identity choice. On the one hand, they could look to their American colleagues for acceptance and support, that is to say, they could aspire to Americanised identities. On the other hand, should they fail to be accepted as honorary Americans, they might have no alternative but to see themselves as either 'victims' or 'freedom-fighters' in an unfair struggle for resources dominated by the Americans. In the current game, therefore, feeling 'British' may well equate to feeling unskilled (the outcome for those who identify closely with their American colleagues) or feeling hard done by (the outcome for those who acknowledge their marginalised status). It is, of course, possible for players' identities to shift from one form to another in a context-dependent way. Indeed, from a figurational perspective, the fragmenting of we-identities is an acknowledged outcome of sports commercialisation (Stokvis 2000). However, whichever form of identity they aspire to, it seems probable that British players would have to work considerably harder than their American colleagues to sustain their motivation, self-confidence and self-esteem.

Given the apparent impact of the Bosman ruling, it is pertinent to consider whether the problems identified in this paper might be eased by alternative forms of legislation. However, it seems that the present situation is being sustained by many factors including: the comparative skills and affordability of the Americans; the enthusiasm of many club 
owners and supporters for a commercial game; and the 'pull' exerted on British players by mainland EU clubs. It is difficult to see how all of these developments might be constrained or reversed through regulation. The application of equal opportunities legislation might be one way forward, but could be difficult to apply in sport, where professional players work to individual contracts and, indeed, are arguably on the verge of self-employed status (Stokvis 2000).

This paper also raises other relevant questions. For example, it is pertinent to ask whether a similar situation would exist in more commercialised forms of basketball. It is certainly possible for commercialisation to work to the benefit of marginalised groups. For example, the commercial development of their home game has allowed Dominican baseball players to establish a commanding international presence, to the point of challenging the Americans' dominance of this sport (Klein 2007). We must also question whether this study's findings would be replicated in other European countries where teams are likely to be less polarised in terms of players' national origin, or whether they would be replicated in less commercialised forms of basketball, such as the British women's game which is still largely amateur but has recently begun to employ professional players. Finally, we should, perhaps, place a question mark against the benign race relations reported by many of this study's participants, given that the British game's working context is dominated by white club owners and directors. All of these questions point to the need for further research.

\section{References}

Adler, P. and Adler, P. (1998). 'Intense loyalty in organizations: a case study of college athletics', in J. van Maanen (ed.), Qualitative Studies of Organizations. London: Sage.

Anderson, N. and Schalk, R. (1998). 'The psychological contract in retrospect and prospect', Journal of Organizational Behaviour, 19, pp. 637-647.

Andersson, M. (2007). 'The relevance of the black Atlantic in contemporary sport: racial imaginaries in Norway', International Review for the Sociology of Sport, 42 (1), pp. 65-81.

BBL (2005). 'It's red hot', Basketball Finals Weekend Programme, 30 April - 1 May 2005. Birmingham: BBL, p.1.

Britball (2000). 'Q\&A: ask the $\mathrm{BBL}^{\prime}$ : available at <http://www.britball.com/features/qnabbl0003.htm>, last accessed 10 August 2007.

Dabscheck, B. (2004). 'The globe at their feet: FIFA's new employment rules - I', Sport in Society, 7 (1), pp. 69-94.

Dabscheck, B. (2006). 'The globe at their feet: FIFA's new employment rules - II', Sport in Society, 9 (1), pp. 1-18.

Dalal, F. (1998). Taking the Group Seriously: Towards a Post-Foulkesian Group Analytic Theory. London: Jessica Kingsley.

Dunning, E. (1993). 'Sport in the civilising process: aspects of the development of modern sport', in E. Dunning, J. Maguire and R. Pearton (eds), The Sports Process: A Comparative and Developmental Approach. Leeds: Human Kinetics.

Elias, N. (2000). The Civilizing Process (revised edition, first published 1939, trans. E. Jephcott). Oxford: Blackwell.

Elias, N. (1978). What Is Sociology? (translation by S. Mennell). New York: Columbia University Press.

Elias, N. and Scotson, J. (1994). The Established and the Outsiders (revised edition, first published 1965). London: Sage. 
Falcous, M. and Maguire, J. (2005). 'Making it local? National Basketball Association expansion and English basketball subcultures', in M.L. Silk, D.L. Andrews, and C.L. Cole (eds), Sport and Corporate Nationalisms. Oxford: Berg.

Falcous, M. and Maguire, J. (2006). 'Imagining 'America': the NBA and local-global mediascapes', International Review for the Sociology of Sport, 41 (1): pp. 59-78.

Flick, U. (2007). Designing Qualitative Research. London: Sage.

Galily, Y. and Sheard, K. (2002). 'Cultural imperialism and sport: the Americanization of Israeli basketball', Culture, Sport, Society, 5 (2), pp. 55-78.

Gardiner, S. and Welch, R. (2000). "Show me the money": regulation of the migration of professional sportsmen in post-Bosman Europe', in A. Caiger and S. Gardiner (eds), Professional Sport in the European Union: Regulation and Re-regulation. The Hague: TMC Asser Press.

Gibbs, G. R. (2007). Analyzing Qualitative Data. London: Sage.

Guba, E. G. and Lincoln, Y. S. (1989). Fourth Generation Evaluation. London: Sage.

Jones, R.L., Armour, K.M. and Potrac, P. (2003). 'Constructing expert knowledge: a case study of a top-level professional soccer coach', Sport, Education and Society, 8 (2), p. 213-229.

Jones, R. L., Glintmeyer, N. and McKenzie, A. (2005). 'Slim bodies, eating disorders and the coach-athlete relationship', International Review for the Sociology of Sport, 40 (3), pp. 377-391.

Jowett, S. (2003). "When the "honeymoon" is over: a case study of a coach-athlete dyad in crisis', The Sport Psychologist, 17, pp. 444-460.

Kelly, S. and Waddington, I. (2006). 'Abuse, intimidation and violence as aspects of managerial control in professional soccer in Britain and Ireland', International Review for the Sociology of Sport, 41 (2), pp. 147-164.

Klein, A. (2007). 'Yo soy Dominicano: hegemony and resistance through baseball', Sport in Society, 10 (6), pp. 916-946.

Lawrence, S. M. (2005). 'African American athletes' experiences of race in sport', International Review for the Sociology of Sport, 40 (1), pp. 99-110.

Lincoln, Y. S. and Guba, E. G. (1985). Naturalistic Inquiry. London: Sage.

Maguire, H. (2002). 'Psychological contracts: are they still relevant?', Career Development International, 7 (3), pp.167-180.

Maguire, J. (1988). 'The commercialisation of English elite basketball 1972-1988: a figurational perspective', International Review for the Sociology of Sport, 23 (4), pp. 305-323.

Maguire, J. (1992). 'Hired corporate guns? Elite sports migrants in the global arena', Vrijetijd en Samenleving, 10 (4), pp. 19-30.

Maguire, J. (1999). Global Sport: Identities, Societies, Civilizations. Cambridge: Polity Press.

McCutcheon, J. P. (2000). 'National eligibility rules after Bosman', in A. Caiger and S. Gardiner (eds), Professional Sport in the European Union: Regulation and Re-regulation. The Hague: TMC Asser Press.

Morgan, W. J. (2006). 'Fair is fair, or is it?: a moral consideration of the doping wars in American sport', Sport in Society, 9 (2), pp. 177-198.

Murphy, P. and Waddington, I. (2007). 'Are elite athletes exploited?', Sport in Society, 10 (2), pp. 239-255.

Olin, K. (1984). 'Attitudes towards professional foreign players in Finnish amateur basketball', International Review for the Sociology of Sport, 19 (3), pp. 273-282.

Parrish, R. and McArdle, D. (2004). 'Beyond Bosman: the European Union's influence upon professional athletes' freedom of movement', Sport in Society, 7 (3), pp 403-419. 
Pate, J. and Goldrick, J. (2003). 'The impact of psychological contract violation on employee attitudes and behaviour', Employee Relations, 25 (6), pp. 557-573.

Poczwardowski, A., Barott, J. E. and Henschen, K. P. (2002). 'The athlete and coach: their relationship and its meaning. Results of an interpretive study', International Journal of Sports Psychology, 33, pp. 116-140.

Potrac, P., Jones, R. and Armour, K. (2002). "It's all about getting respect": the coaching behaviors of an expert English soccer coach', Sport, Education and Society, 7 (7), pp. 183-202.

Roderick, M. (2006). 'Adding insult to injury: workplace injury in English professional football', Sociology of Health and IIIness, 28 (1), pp. 76-97.

Roderick, M., Waddington, I. and Parker, G. (2000). 'Playing hurt: managing injuries in English professional football', International Review for the Sociology of Sport, 35, pp. 165-180.

Sabo, D., Miller, K. E., Melnick, M. J., Farrell, M. P. and Barnes, G. M. (2005). 'High school athletic participation and adolescent suicide: A nationwide US study'. International Review for the Sociology of Sport, 40 (1), pp. 5-23.

Seippel, $\varnothing$. (2006). 'The meanings of sport: fun, health, beauty or community?', Sport in Society, 9 (1), pp. 51-70.

Stokvis, R. (2000). 'Globalization, commercialization and individualization: conflicts and changes in elite athletics', Culture, Sport, Society, 3 (1), pp. 22-34.

Taylor, R. (1999). 'Home talent exodus endangers England', The Independent, 6 March 1999, p.25.

Taylor, R. (2002). 'No room at home for young hopefuls', The Independent, 19 January 2002, p.22.

Viner, B. (2003). 'Amaechi sticks to his guns in fight with coach', The Independent, 7 June 2003, p. 6.

Waddington, I. and Murphy, P. (1992). 'Drugs, sport and ideologies', in E. Dunning and C. Rojek (eds), Sport and Leisure in the Civilizing Process: Critique and Counter-critique. Toronto: University of Toronto Press.

Walton, T. (2001). 'The Sprewell/Carlesimo episode: unacceptable violence or unacceptable victim?', Sociology of Sport Journal, 18 (3), pp. 345-357.

Wilson, J. (1992). 'Cleaning up the game: perspectives on the evolution of professional sports', in E. Dunning and C. Rojek (eds), Sport and Leisure in the Civilizing Process: Critique and Counter-critique. Toronto: University of Toronto Press. 